\title{
Food safety knowledge levels of gastronomy/culinary arts students and food workers in Southern Turkey
}

\section{Mevhibe TERKURAN}

Cite this article as:

Terkuran, M. (2021). Food safety knowledge levels of gastronomy/culinary arts students and food workers in Southern Turkey. Food and Health, 7(3), 203-215. https://doi.org/10.3153/FH21022

Osmaniye Korkut Ata University, Kadirli School of Applied Sciences, Department of Gastronomy and Culinary Arts, Osmaniye, Turkey

ORCID IDs of the authors: M.T. 0000-0002-3150-459X

\section{Submitted: 25.12 .2020}

Revision requested: 21.01 .2021

Last revision received: 14.02 .2021

Accepted: 15.02 .2021

Published online: 18.05 .2021

Correspondence:

Mevhibe TERKURAN

E-mail: mevhibeterkuran@korkutata.edu.tr

\section{ABSTRACT}

This research was aimed to analyze the food safety knowledge levels between gastronomy and culinary arts students and food workers in the Çukurova Region of Turkey. A total of 155 participants (80 students, 75 food workers) have participated in this cross-sectional study. The overall knowledge scores of food workers and the students were $89.33 \%$ and $78.89 \%$ respectively, and food workers have more scores in all sections $(\mathrm{p}<0.001)$. Hygiene certification, occupation, and working establishments had a significant association with total food safety scores; however, gender, marital status, age, education level, frequency of hygiene education, working experience, monthly income had no significant association with their scores $(p>0.05)$. A positive correlation was found between gender, education status, hygiene certification, and frequency of receiving hygiene education; but no correlation was found between working in any food business, graduated high schools, and age of the students $(\mathrm{p}>0.05)$. More knowledge gaps of both groups have been found about time-temperature control, holding/storage temperature, and cross-contamination. Finally, it is important to measure the reflection of the hygiene training on practices and to make it regular in ensuring food safety.

Keywords: Food safety, Food workers, Culinary art students

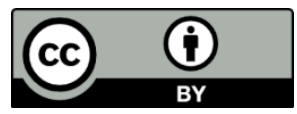

(C) 2021 The Author(s)

Available online at http://jfhs.scientificwebjournals.com 


\section{Introduction}

Foodborne diseases and infections have become important rising public-health problems because of increased morbidity and mortality rates around the world (Taylor et al., 2015). This problem has not only negatively affected developing countries but also has effected negatively in developed countries. Moreover, foodborne diseases cause crucial social and financial problems in countries as well as their health system (Akoğlu et al., 2017; Draeger et al., 2019). Considering the main reason for these diseases around the world has shown that mass catering and food service facilities are the most frequent cause of foodborne outbreaks. Besides, the plurality of those outbreaks arises from wrong/ inappropriate applications during food handling processes (Giritlioglu et al., 2011; Taha et al., 2020). Like other countries worldwide, foodborne diseases have been an important problem in our country, which was the result of economic crises and negative effects on public health. Moreover, the distribution of foodborne diseases in our country is less known because reporting of foodborne illness to official authorities is less in our country.

Food workers are the most important key factor to prevent foodborne diseases in the way of their direct contact with the foods. Moreover, during the preparation steps in the foodproducts, they have an active role in transmitting the foodborne pathogens to the consumers because of their insufficient awareness level of food safety (Akoğlu et al., 2017; Alqurashi et al., 2019; Taha et al., 2020).

The main purpose of the gastronomy and culinary arts departments is to educate students on different food establishments as food and beverage management and provide knowledge to be a manager or staff in several food products operations. After graduation, students will work as managers or food workers in a number of cafeterias. On the other hand, food safety knowledge levels of food workers in the area and what kind of training should be given routinely to them are so critical to contribute to food safety in public health. Therefore, a comparative assessment of food workers and the students' knowledge and attitudes about food hygiene and safety are so essential to provide their safe food preparation and designing well training for their education/application. These factors are analyzed in the present study.

\section{Materials and Methods}

\section{Sample Collection and Study Design}

A questionnaire form was prepared to measure students' and food workers' knowledge and experience of food hygiene and safety by taking into consideration of validated previous studies (Baş et al., 2006; Giritlioglu et al., 2011; Osaili et al.,
2018). Before the data collection, randomly selected participants have pre-tested the questionnaire. After this pre-test application, the questionnaire calibration was made including some questions that were transformed to be more clear and understandable for the participants (pre-test data not shown). The data were collected from gastronomy and culinary arts students and food workers with face-to-face and online interviews, from 15 February to 29 May 2020. The aim of the study and methodology was explained to the participants and those who agreed to participate in the study were asked to sign a consent form.

The questionnaire form was consisting of four sections (sections A, B, C, and D). In section (A), the determining of food workers' and the students' socio-demographic characteristics with 9 and 8 questions, respectively. In this section, the demographic characteristics of the participants, gender, age, working time, amount of the salary of the food workers; hygiene education and certification status, working experience in any food business, and schools where they were graduated were asked to the students. In section (B), the participants were given 14 questions to evaluate their level of knowledge about food hygiene and safety. In this section, there are information questions about food workers and students' kitchen hygiene, food safety, cross-contamination, food poisoning, disease-borne microorganisms, time and temperature control, and regulation about hygiene education of food workers. In response, they were asked to choose between 'correct', "wrong" or "don't know'. The third section (C) contains 9 questions about safe food production practices. In response, they were asked to "'agree", ' 'no idea' 'or ''disagree'. In the last section (D), two questions were graded using a 5-point Likert scale ranging from "always "'(4)" to "never (0)". The reason for using the Likert scale in section $\mathrm{D}$ is that hand washing after toilet and sneezing is very important in bacterial and viral transmission (Lund, 2015; Mehta, 2020). For this reason, it was thought to measure how often this hygiene practice was applied. The total food safety knowledge score of the participants was calculated by adding the correct answers to 25 questions in three categories (maximum score is 100) (Baş et al., 2006; Osaili et al., 2017). In sections B and D; each correct answer was given ' 4 "' points, but other answers (wrong or don't know/any idea or disagree) were awarded " 0 " points (the maximum scores for sections (B) and (D)are ' 56 '" and ' 36 ', respectively). In section C; always, often, sometimes, rarely and never answers were given as '"4', ' 3 ', ' '2', ' '1', and ' 0 ', points, respectively. The maximum score for section (C) is " 8 ". 


\section{Statistical Analysis}

The IBM SPSS Statistics Version 20.0 statistical software package was used for data analysis. Categorical variables were expressed as numbers and percentages, whereas continuous variables were summarized as mean and standard deviation and as median and minimum-maximum where appropriate. A Chi-Square test was used to compare categorical variables between the two groups. For comparison of continuous variables between two groups, the Student's t-test or Mann-Whitney U test was used depending on whether the statistical hypotheses were fulfilled or not. For comparison of more than two groups, One way ANOVA or Kruskal Wallis test was used depending on whether the statistical hypotheses were fulfilled or not. P-value used in tables 3, 4, 5, and 6; Mann Whitney test (MW) result is 0.284 , T-test $(\mathrm{t})$ is 0.005 , for Anova (A), it is 0.348 , and Kruskal-Wallis (KW) is 0.325 . The test statistic values and degree of freedom were not given in tables to keep the tables easy to understand. The statistical level of significance for all tests was considered to be 0.05 .

\section{Results and Discussion}

The results have been analyzed in six categories. Section A: Demographic characteristics of the participants. Section B: Frequency and percentage levels of participants' safe food practices. Section C: Safe food production practices. Section
D: Personal hygiene practices of the participants. Section E: Total food safety knowledge scores of the participants and section F: The relationships between demographic profiles and the scores of each section of the questionnaire.

\section{Section A: Demographic Characteristics of Participants}

Considering the food workers in Table 1: The majority of them male ( $84 \%$ male; $16 \%$ female). Because of tough hardworking conditions/cultural factors, females generally do not prefer working in food-production businesses. This result is in line with previous studies in Turkey (Baş et al., 2006; Çakıroğlu and Uçar, 2008; Tuncer and Akoğlu, 2020). Eighty-three percent of them were married. About $47 \%$ of food workers were between 30 and 40 years old, and 28\% > 40 years old. The percentage of food workers with experience 0 and 6 years, $6-11$ years, $12-20$ years, and $>20$ years were $23,41,24$, and $12 \%$, respectively. Besides, $73 \%$ of them were working in catering restaurants (seven restaurants) and $27 \%$ of them working in kebab restaurants (four restaurants). Regarding education, $32,39,20$, and $9 \%$ of the participants had primary, secondary, high school, and higher (college/university) education levels, respectively. In our study, the number of food workers who graduated from the university is low $(9 \%)$ and the result of this study is comparable with the studies performed by Tuncer and Akoğlu's (2020) results.

Table 1. Demographic characteristics of the participants (Section A)

\begin{tabular}{|c|c|c|c|c|c|}
\hline \multirow[t]{2}{*}{ Demographic factors } & & \multicolumn{2}{|c|}{ Food Workers $(n=75)$} & \multicolumn{2}{|c|}{ The Students $(n=80)$} \\
\hline & & Freq. & $(\%)$ & Freq. & $(\%)$ \\
\hline \multicolumn{6}{|l|}{ Gender } \\
\hline Male & & 63 & 84 & 54 & 67.5 \\
\hline Female & & 12 & 16 & 26 & 37.5 \\
\hline \multicolumn{6}{|l|}{ Age(years) } \\
\hline$<30$ & $18^{*}$ & 19 & 25 & 11 & 13.8 \\
\hline $30-40$ & $19^{*}$ & 35 & 47 & 19 & 23.8 \\
\hline$\geq 40$ & $\geq 20 *$ & 21 & 28 & 50 & 62.5 \\
\hline \multicolumn{6}{|c|}{ Education / Graduated High School* } \\
\hline Primary school & Profession* & 24 & 32 & 21 & 26.2 \\
\hline Secondary school & Anatolia* & 29 & 39 & 42 & 52.5 \\
\hline High school & Open* & 15 & 20 & 6 & 7.5 \\
\hline Collage (university) & Religious* & 7 & 9 & 11 & 13.8 \\
\hline \multicolumn{6}{|l|}{ Hygiene certification } \\
\hline Certificated & & 68 & 91 & 5 & 6.2 \\
\hline Not certificated & & 7 & 9 & 75 & 93.8 \\
\hline \multicolumn{6}{|l|}{ Hygiene education } \\
\hline Once & & 47 & 63 & 51 & 63.7 \\
\hline 2 or 3 times & & 21 & 28 & 15 & 18.8 \\
\hline$\geq 4$ times & & 7 & 9 & 14 & 17.5 \\
\hline
\end{tabular}

\footnotetext{
* Questions of the students
} 
The continuous of Table 1 .

\begin{tabular}{|c|c|c|c|c|c|}
\hline \multirow[t]{2}{*}{ Demographic factors } & & \multicolumn{2}{|c|}{ Food Workers $(n=75)$} & \multicolumn{2}{|c|}{ The Students $(n=80)$} \\
\hline & & Freq. & $(\%)$ & Freq. & $(\%)$ \\
\hline Occupation & Education status* & & & & \\
\hline Cook & Class one* & 34 & 45.4 & 44 & 55 \\
\hline Assistant cook & & 16 & 21.3 & & \\
\hline Waiter & Class two* & 12 & 16 & 36 & 45 \\
\hline Others (participant, steward, manager) & & 13 & 17.3 & & \\
\hline Working experience (years) & Working in any food business* & & & & \\
\hline $0-6$ & Yes* & 17 & 23 & 32 & 40 \\
\hline $6-12$ & & 31 & 41 & & \\
\hline $12-20$ & No* & 18 & 24 & 48 & 60 \\
\hline$\geq 20$ & & 9 & 12 & & \\
\hline \multicolumn{6}{|l|}{ Monthly income(Turkish Liras) } \\
\hline $2500-3000$ & & 47 & 63 & & \\
\hline $3000-3500$ & & 24 & 32 & & \\
\hline $3500-4000$ & & 4 & 5 & & \\
\hline \multicolumn{6}{|l|}{ Marital status } \\
\hline Married & & 62 & 83 & & \\
\hline Single & & 13 & 17 & & \\
\hline \multicolumn{6}{|l|}{ Working area } \\
\hline Catering & & 55 & 73 & & \\
\hline Kebab restaurant & & 20 & 27 & & \\
\hline
\end{tabular}

* Questions of the students

In their study, $14 \%$ of food workers who worked in hotels had a bachelor's degree. The distribution rate of occupations for food workers; the cook was $45.4 \%$, and $16 \%$ was waiter, respectively. The percentage of the participants who had taken food safety training (once) was $63 \%$ and $91 \%$ of them had a hygiene certificate. The training rate of the food workers was lower than the study of Tuncer and Akoğlu's study (2020). In their work, $82.3 \%$ of food processors previously joined training courses on food safety. Considering the students; $67.5 \%$ of the participants were males, $62.5 \%$ of them were $\geq 20$ years old. In addition, $52.5 \%$ of them graduated from Anatolia High schools, $93.8 \%$ of them have no hygiene certificate, $40 \%$ of them working in a food establishment, $55 \%$ of them were in first-class (freshmen), and $45 \%$ of the second class (sophomore) in the university.

\section{Section B: Frequency and Percentage Levels of Participants' Safe Food Production Levels}

The results are shown in Table 2 . As this table shows, nearly all students $(98.75 \%)$ and all food workers $(100 \%)$ agreed that ignoring food hygiene rules during food production caused foodborne diseases. These results are similar to a study about cookery students by Giritlioglu et al. (2011) and by a study about hospital food workers by Tokuc et al. (2009). Both studies reported (90.02\%) about this item.

Monitoring of holding temperature of hot ready-to-eat food is an important preventive method of foodborne illness. For example, Clostridium perfringens create heat-resistant spores that are not inactivated by cooking. Therefore, meals that are not eaten immediately but are prepared before should be cooled correctly and stored meals should be heated to at least $74^{\circ} \mathrm{C}$ for 15 seconds before consumption (Lund, 2015). The ideal holding temperature of hot ready-to-eat food should be more than $\geq 63^{\circ} \mathrm{C}$ (EFSA and ECDC, 2015). Our results show that $23.75 \%$ of students and $77 \%$ of food workers had accurate information about this item. Students' findings are lower but food workers' findings are higher than the previous study of Giritlioglu et al. (2011). In their study, about $48.8 \%$ of food workers knew the right temperature. In the two groups, 13\% of food workers and $23.75 \%$ of students gave correct answers to the question of "bacteria don't proliferate at $90^{\circ} \mathrm{C}$. And $37.5 \%$ of students had no idea about it. The majority of food workers $(87 \%)$ and $38.75 \%$ of the students have incorrect information about the temperature of bacterial proliferation in foods. Our results were lower than Giritlioglu and colleagues' (2011) results; their results were 56\% about this item. Proba- 
ble causes of our results are lack of information about bacterial growing in ready-to-eat foods. Another question was "only ill people carry bacteria which may cause food poisoning", $25 \%$ of food workers and $3.75 \%$ of students knew the correct answers. Besides, $7.5 \%$ of students have chosen no idea about it. Both of our groups' results were lower than the previous study by Ncube et al. (2020). In their study, 78.2\% of the participants knew the correct answers to this question. These findings show that participants did not understand the risk of food contamination that an unsanitized food worker posed. Like our results, some studies reported that food workers lacked adequate knowledge about the risk of contamination of food by diarrheal food workers (Clayton et al, 2002; Osaili et al., 2011). In contrast, some studies have demonstrated that food workers have good knowledge about this issue (Da Cunha et al., 2014; Pichler et al., 2014). Considering the other question that "bacterial proliferation stop at body temperature $\left(37^{\circ} \mathrm{C}\right) ", 12 \%$ of students and $32.5 \%$ of food workers answered this question correctly, but $15 \%$ of students have chosen 'no idea'" about it. Akoğlu et al. (2017) found both of our groups' results lower than the previous study. In their study; $89.4 \%$ of the participants gave correct answers to this item.

Improper thawing application of frozen poultry and red meat can cause food poisoning. During the thawing process, the temperature becomes permissive for bacterial growth (Marriott and Gravani, 2006). Thawing food in room temperature keeps food temperature at a danger zone for a long time. This condition fosters microbial growth, which may cause food poisoning. The methods of thawing the frozen meat/poultry are; thawing at refrigerator temperature $\left(5^{\circ} \mathrm{C}\right.$; app. whole day), in a microwave or cold water (app. an hour by changing the water every 30 minutes) (USDA, 2013). Temperature control of the meat is an important way to prevent poisoning, like thawing in a refrigerator. In this study, $71 \%$ of food workers and $58.7 \%$ of students did not thaw frozen meat at room temperature in proportion to the $64.6 \%$ result of a recent study in Turkey (Akoğlu and Tuncer, 2017); food workers' scores were higher but our students' scores were lower than Akoğlu and Tuncer's study (2017). Besides, both of our group's knowledge levels were higher than some previous studies such as 38.2\% in China (Gong et al., 2016), 66\% in Kuwait (Al-Kandari et al., 2019), and 54\% in the United Arab Emirates (Taha et al., 2020). On the other hand, 87.5\% of students and $74.6 \%$ of food workers knew that re-freezing of thawed foods causes foodborne diseases. However, 8.75\% and $22.7 \%$ of them did not know this item, respectively. And $3.75 \%$ of students and $2.7 \%$ of food workers had no idea about this subject. Our two groups' results were lower than Akoğlu and Tuncer's (2017) reports. In their study, 92\% of gastronomy and culinary arts students gave the correct answer to the aforementioned question. In contrast, our results were higher than Sani and Siow's (2014) studies, in which about $75 \%$ of the respondents were certain about refreezing defrosted food.

Table 2. Food safety knowledge, safe food production and personal hygiene practices of the participants

\section{Food Safety Knowledge (Section B)}

1. Failure to comply with the hygiene rules in the preparation of foods, causes foodborne illness

\section{Incorrect heating of food causes foodborne illness}

3. Foods that are ready to eat should be stored at $20^{\circ} \mathrm{C}$

4. In ready-to-eat foods, bacteria multiply at about $90^{\circ} \mathrm{C}$

5. Bacteria that cause food poisoning are only transmitted by sick people

6. Bacteria stop proliferation at body temperature $\left(37^{\circ} \mathrm{C}\right)$

7. Frozen chicken and red meat should be thawed at room temperature

8. Re-freezing of thawed foods can cause foodborne illness

9. After cooked foods cool down to $21^{\circ} \mathrm{C}$ at room temperature, they should be put in the refrigerator / cold storage

10. The same cutting board can be used for chopping and cutting different types of meat (red meat, chicken, fish, etc.)

11. The same cutting board can be used to chop meat and vegetables

12. Salmonella is an important bacterium that causes food poisoning

13. Food should be served no later than two hours after preparation 14. Food production personnel must have a hygiene certificate

*Students' answers were given after "/,"

**Correct answers are given in bold type

The Given Answers of Food Workers and Students*

\begin{tabular}{|c|c|c|c|c|c|}
\hline \multicolumn{2}{|c|}{ Correct } & \multicolumn{2}{|c|}{ Wrong } & \multicolumn{2}{|c|}{ Don't know } \\
\hline Freq. & $\%$ & Freq. & $\%$ & Freq. & $\%$ \\
\hline $75 / 79$ & $100 / 98.75$ & $-/ 1$ & $-/ 1.25$ & $-/-$ & $-/-$ \\
\hline $75 / 74$ & $100 / 92.5$ & $-/ 3$ & $-/ 3.75$ & $-/ 3$ & $-/ 3.75$ \\
\hline $17 / 31$ & $23 / 38.75$ & $58 / 19$ & $77 / 23.75$ & $-/ 30$ & $-/ 37.5$ \\
\hline $65 / 31$ & $87 / 38.75$ & $10 / 27$ & $13 / 33.75$ & $-/ 22$ & $-/ 27.5$ \\
\hline $56 / 71$ & $75 / 88.75$ & $19 / 3$ & $25 / 3.75$ & $-/ 6$ & $-/ 7.5$ \\
\hline $66 / 42$ & $88 / 52.5$ & $9 / 26$ & $12 / 32.5$ & $-/ 12$ & $-/ 15$ \\
\hline $21 / 27$ & $28 / 33.75$ & $53 / 47$ & $71 / 58.75$ & $1 / 6$ & $1 / 7.5$ \\
\hline $56 / 70$ & 74.6/87.5 & $17 / 7$ & $22.7 / 8.75$ & $2 / 3$ & $2.7 / 3.75$ \\
\hline $72 / 48$ & $96 / 60$ & $3 / 18$ & $4 / 22.5$ & $-/ 14$ & $-/ 17.5$ \\
\hline $69 / 60$ & $92 / 75$ & $6 / 13$ & $8 / 6.25$ & $-/ 7$ & $-/ 8.75$ \\
\hline $70 / 66$ & $93 / 82.5$ & $5 / 9$ & 7/11.25 & $-/ 5$ & $-/ 6.25$ \\
\hline $65 / 41$ & $87 / 51.25$ & $4 / 23$ & $5 / 28.75$ & $6 / 16$ & $8 / 20$ \\
\hline $71 / 51$ & $95 / 63.75$ & $3 / 19$ & $4 / 23.75$ & $1 / 10$ & $1 / 2.5$ \\
\hline $75 / 76$ & $100 / 95$ & $-/ 2$ & $-/ 2.5$ & $-/ 2$ & $-/ 2.5$ \\
\hline
\end{tabular}


The continuous of table 2 .

\begin{tabular}{|c|c|c|c|c|c|c|c|c|c|c|}
\hline \multirow{2}{*}{\multicolumn{5}{|c|}{ Safe Food Production Practices (Section C) }} & \multicolumn{2}{|c|}{ Agree } & \multicolumn{2}{|c|}{ No idea } & \multicolumn{2}{|c|}{ Disagree } \\
\hline & & & & & Freq. & $\%$ & Freq & $\%$ & Freq. & $\%$ \\
\hline \multicolumn{5}{|c|}{$\begin{array}{l}\text { 1. Food safety is an important matter in the food sector. Therefore, } \\
\text { I attending to my personal hygiene }\end{array}$} & 75/76 & $100 / 95$ & $-/ 3$ & $-/ 3.75$ & $-/ 1$ & $-/ 1.25$ \\
\hline \multicolumn{5}{|c|}{ 2. In food production processes, I always prefer fresh raw materials } & $75 / 78$ & $100 / 97.5$ & $-/ 2$ & $-/ 2.5$ & $-/-$ & $-/-$ \\
\hline \multirow{2}{*}{\multicolumn{5}{|c|}{$\begin{array}{l}\text { 3. If my hands or fingers are cut, I never contact raw/cooked food. } \\
\text { 4. I wear protective materials (cap, mask, and gloves) during food } \\
\text { production to avert foodborne illness }\end{array}$}} & 75/72 & $100 / 90$ & $-/ 6$ & $-/ 7.5$ & $-/ 2$ & $-/ 2.5$ \\
\hline & & & & & $75 / 78$ & $100 / 97.5$ & $-/-$ & $-/-$ & $-/ 2$ & $-/ 2.5$ \\
\hline \multicolumn{5}{|c|}{$\begin{array}{l}\text { 5. To ensure safe food production, my working area always remains } \\
\text { clean }\end{array}$} & $75 / 80$ & $100 / 100$ & $-/-$ & $-/-$ & $-/-$ & $-/-$ \\
\hline \multirow{2}{*}{\multicolumn{5}{|c|}{$\begin{array}{l}\text { 6. I don't wear my uniform and shoes outside my workspace } \\
\text { 7. Without wearing protective gloves, I don't contact raw foods } \\
\text { (especially raw meat, eggs, chicken meat, etc.) }\end{array}$}} & $74 / 70$ & $98.7 / 87.5$ & $-/ 3$ & $-/ 3.75$ & $1 / 7$ & $1.3 / 8.75$ \\
\hline & & & & & $75 / 65$ & $100 / 81.25$ & $-/ 9$ & $-/ 11.25$ & $-/ 6$ & $-/ 7.5$ \\
\hline \multicolumn{5}{|c|}{$\begin{array}{l}\text { 8. During food production processes, I don't wear jewelry such as } \\
\text { rings, earrings, and watches }\end{array}$} & $74 / 79$ & $98.7 / 98.75$ & $-/-$ & $-/-$ & $1 / 1$ & $1.3 / 1.25$ \\
\hline \multicolumn{5}{|c|}{$\begin{array}{l}\text { 9. When I have the flu, cold or diarrhea, etc. I don't work in the } \\
\text { production line }\end{array}$} & $75 / 73$ & $100 / 91.25$ & $-/ 2$ & $-/ 2.5$ & $-/ 5$ & $-/ 6.25$ \\
\hline \multirow{2}{*}{$\begin{array}{l}\text { Personnel Hygiene } \\
\text { Practices (Section D) }\end{array}$} & \multicolumn{2}{|c|}{ Always } & \multicolumn{2}{|c|}{ Often } & \multicolumn{2}{|c|}{ Sometimes } & \multicolumn{2}{|c|}{ Rarely } & \multicolumn{2}{|c|}{ Never } \\
\hline & Freq. & $\%$ & Freq. & $\%$ & Freq & $\%$ & Freq. & $\%$ & Freq. & $\%$ \\
\hline $\begin{array}{l}\text { 1. How often do you } \\
\text { wash your hands af- } \\
\text { ter using the toilet? }\end{array}$ & $75 / 80$ & $100 / 100$ & $-/-$ & $-/-$ & $-/-$ & $-/-$ & $-/-$ & $-/-$ & $-/-$ & $-/-$ \\
\hline $\begin{array}{l}\text { 2. Do you wash your } \\
\text { hands after coughing } \\
\text { or sneezing? How } \\
\text { often? }\end{array}$ & $75 / 34$ & $100 / 42.5$ & $-/ 32$ & $-/ 40$ & $-/ 9$ & $-/ 11.25$ & $-/ 3$ & $-/ 3.75$ & $-/ 2$ & $-/ 2.5$ \\
\hline
\end{tabular}

*Students' answers were given after "/,

**Correct answers are given in bold type

Inappropriate temperature/time control and cooling of the cooked/pre-cooked foods are the most common cause of foodborne diseases. According to the World Health Organization (WHO), nearly $75-85 \%$ of all foodborne illness results from time/temperature misuse, and $56 \%$ of them result from improper cooling. After cooked/pre-cooked foods should be kept at over $60^{\circ} \mathrm{C}$ to prevent the growth of food poisoning bacteria. In general, between $5^{\circ} \mathrm{C}$ and $63^{\circ} \mathrm{C}$ is considered a " danger zone" in which those bacteria can grow quickly at this temperature range. Proper cooling procedures for cooked or pre-cooked foods have been explained by the literature. Briefly; after cooking, a two-stage cooling method is commonly applied to prevent bacterial growth in the food. The first step consists of cooling the food product from $60^{\circ} \mathrm{C}$ to $21^{\circ} \mathrm{C}$ in 2 hours, instead, in the second step, cooling takes place for up to 4 hours from $21^{\circ} \mathrm{C}$ to $5^{\circ} \mathrm{C}$. The first step just mentioned is the most critical because microbial growth of the bacteria at temperatures between $51^{\circ} \mathrm{C}$ and $21^{\circ} \mathrm{C}$ is usually faster than low temperatures (US FDA, 2017). The questions about time/temperature control and cooling were the most frequently answered incorrectly by the respondents according to some previous studies. Our food workers' results were higher than some recent studies (Gomes-Neves et al.,
2014; Al-Kandari et al., 2019). In their study, food workers had less knowledge about time and temperature control (45 and $63 \%)$, respectively. However, our students' results $(60 \%)$ were lower than Al- Kandari et al. (2019)'s study but over than Al-Shabib et al. (2016)'s study. However, 22.5\% of students and $4 \%$ of food workers gave wrong answers to that "after cooked foods cool down to $21^{\circ} \mathrm{C}$ at room temperature, they should be put in the refrigerator / cold storage" in our study. Moreover, $17.5 \%$ of students had no idea about this issue. Food workers have more information/awareness about correct cooling practices than the students do. These results might be based on the working experience. Other findings are that only $16.25 \%$ of the students and $8.75 \%$ of food workers were aware that red meat and poultry meat cannot be chopped together on the same cutting board, and that $82.5 \%$ of students and $93 \%$ of food workers were not aware of it is hazardous in terms of cross-contamination. Our results are lower than the previous study by Taha et al. (2020). In their study, $39.5 \%$ of food workers were not aware of these items. The possible causes of our results might be the participants were less informed about the importance and relationships between cross-contamination and food poisoning in their training/education period. Salmonella is a Gram-negative bacterium that 
is important food-borne pathogens and responsible for several outbreaks worldwide and this pathogen might be transmitted by food workers' lack of hygiene application (Sun et al., 2020). In our study, $52.25 \%$ of the students and $87 \%$ of food workers knew that this bacteria can cause serious food poisoning. These results were higher than the results of Alqurashi et al. (2019). In their study, 7.6\% of the hospital food workers in Saudi Arabia knew that Salmonella is an important bacterium that causes food poisoning.

Microorganisms reproduce rapidly in foods kept in room conditions. Therefore, cooked foods that are not stored in the refrigerator deteriorate in a short time. If these foods are not consumed immediately, they should be kept in refrigerator conditions after they cool down quickly (Lund, 2015). Most of our respondents answered this item correctly. Sixty-three point eight percent of the students and $95 \%$ of food workers knew that food should be served no later than two hours after preparation. However, in the present study, almost a quarter of the students $(23.75 \%)$ were unaware of this risk. Our results were higher than Osaili et al.'s (2018) study. They reported that a small part of the participants $(15 \%)$ had known the correct retention temperature needed to eat. Besides, the results of the students were lower than Güven and his colleague's (2010) results. However, our food worker's results were higher than the results of Güven et al.'s (2010) study. In their study, $10.9 \%$ of food workers were not aware of this item, and $89.1 \%$ of their respondents knew that "Cooked foods should be consumed immediately or if they are to be consumed later it should be stored in the refrigerator after cooling down quickly". Also, while $95 \%$ of students and $100 \%$ of food workers knew that the staff involved in food production had a hygiene certificate before operating food businesses, they knew that a hygiene certificate was needed according to European and Turkish legislation (EC 2004; Anonymous, 2013).

\section{Section C: Safe Food Production Practices}

These results are shown in Table 2 . The table indicates that almost all students (95\%) and all food workers (100\%) shown a high-level consideration of personal hygiene. Ninety percent of the students and $100 \%$ of food workers were aware that severe foodborne diseases can be caused by hand or finger injury. This result was in agreement with a study by Tokuc et al. (2009) and higher than the study of Al-Kandari et al. (2019). They found that almost $93.2 \%$ of the food workers in hospitals and $85 \%$ of food workers in Kuwait Restaurants were knowledgeable about the risk of touching on the food with cut hands or fingers, respectively.

The use of protective equipment is one of the most important prerequisites in the food production line. In each step of food production and service processes, In order to prevent microbial contamination, food personnel should wear masks, caps, and gloves. Nearly all students $(97.5 \%)$ and all food workers $(100 \%)$ stated that they used all protective types of equipment in each step of food production. Our results were parallel to previous studies conducted in Saudi Arabia and Turkey; Alqurashi et al.'s (2019), Çakiroglu and Uçar's (2008) studies. They reported similar results in their study in which $82.2 \%$ (cap), $70.6 \%$ (mask), $81 \%$ (gloves), and $82.9 \%$ of the hospital food staff and food workers put on caps, masks, and gloves all along with the food production processes, respectively. In the present study, all of the respondents (100\%) indicated that they always keep clean in their working area to maintain safe food production. Also, $87.5 \%$ of the students and $98.7 \%$ of the food workers clarified that they did not dress in the work shoes and clothes outside of their working area. Our results were similar to Giritlioglu et al.(2011). In their study, $90.2 \%$ of cookery students stated that they did not use working clothes and shoes outside their workspace.

According to literature; "people's throat, nose, intestines, and feces are loaded with bacteria" thus, the human is the potential source of both saprophyte and pathogenic microorganisms in foods. Therefore, food workers play a crucial role in the transmission of respiratory (cold, angina, pneumonia and covid-19 diseases, tuberculosis, scarlet fever) and digestive (dysentery, cholera, typhoid) disease factors (Palulu, 2014; Mehta, 2020). For all these reasons, it is so important to use an apron, gloves, cap, arm sleeve, and to comply with personal hygiene rules during each step of food preparation. According to our study, most of the students $(81.7 \%)$ stated that they did not touch raw food without wearing protective gloves and most of them (84.2\%) stated that they did not wear jewelry during food production. Palulu (2014) reported that $97.2 \%$ of food workers put off their jewelry before starting in food handling. On the other hand, Al-Shabib et al. (2016) indicated in their study that about $75.9 \%$ of street vendors in Saudi Arabia are knowledgeable that wearing accessories in the food processing area could cause bacterial contamination. Most of the students (89\%) stated that they do not deal with food when they have flu, cold, or diarrhea. Similarly, this rate had been reported as $86.2 \%$ in Al-Shabib et al.'s (2016) study. Our results indicate that the students were aware of the risk of unhealthy personnel working in the food production area and that their education had successfully taught them, that infections can be easily transmitted under this kind of condition. 


\section{Section D: Personal Hygiene Practices}

These results are presented in Table 2. Handwashing is an essential behavior for providing food safety and has a crucial role in eliminating bacteria and viruses. Recently, this hygiene practice has become the most important issue due to the spreading of the Sars CoV-2 virus and the subsequent efforts to prevent the spread of the virus worldwide. People who are asymptomatically infected can secrete some amount of bacteria or viruses for a long time, and those with symptoms can continue to secrete the pathogenic microorganisms after getting rid of the symptoms of infection. No matter how hygienically stored, prepared, cooked, or kept food can be contaminated with food by dirty hands and dirty tools. Therefore, effective hand washing (at least 20 seconds including each part of the hands) and good hygiene practices for food workers are so crucial to prevent the risk of infection (Lund, 2015; Mehta, 2020). Table 4 shows that $100 \%$ of all respondents stated that hand washing was important after using the toilet and 100\% of food workers stated that hand washing was also so important after coughing and sneezing. Considering the other studies, our food workers' results were similar to Osaili et al.'s (2017) study but higher than Tokuc et al.'s (2009) reports. Their findings were $99.2 \%$ and $93.2 \%$, respectively in this manner. In other results about personal hygiene, $100 \%$ of food workers and $42.5 \%$ of the students indicated that they always washed their hands after coughing or sneezing, while $40 \%$ of them answered as "often". The students' results in the present study were lower than previous studies of Darko et al. (2015) and Osaili et al. (2017). In their studies, 87.2 and $91.2 \%$ of the kitchen staff knew the correct time to wash their hands, respectively. Our results indicated that the students have lower attention to hygiene -need more education about this subject- than other necessities about food safety.

\section{Section E: Assessment of Total Food Safety Knowledge Scores among Food Workers and Students}

Table 3. indicated that a statistically significant difference was found between the food safety knowledge, food safety practice, and personal hygiene total scores of the students and food workers $(p<0.001)$. Between the two groups; food safety knowledge, food safety practice, and personal hygiene total scores of food workers were found to be statistically higher than the students $(p<0.001)$. As seen in Table 3; the overall score of food safety knowledge aspects of food workers was $45.44 \pm 5.41$ out of 56 points, corresponding to $81.20 \%$ of questions answered correctly. This score was $38.35 \pm 12.37$ in Gastronomy students and corresponding to $68.48 \%$ of questions answered correctly by them. The food safety practices aspect of food workers was $35.89 \pm 0.92$ out of 36 points, corresponding to $99.70 \%$ of questions answered correctly by them. However, this score was 33.55 \pm 3.34 in Gastronomy students and corresponding to $93.20 \%$ of questions in this section answered correctly by them. Personnel Hygiene Practices aspect was scored the highest percentage of correct food workers $(100 \%)$, whereas this rate was measured as $87.38 \%$ in the students. Table 4. shown that between the two groups; total food safety knowledge, food safety practice, and personal hygiene scores of food workers $(89.33 \%)$ were found to be higher than the students' scores $(78.89 \%)(\mathrm{p}<0.001)$. Total food safety knowledge level of each group [89.33\% (food workers), $78.79 \%$ (the students) respectively] and total mean scores $(83.94 \%)$ of both groups shown in the current study were higher than the results of some previous studies in the Middle East and European countries; Dubai and Sharjah (70\%) (Taha et al., 2020), in Kuwait (70\%) (Al-Kandari et al., 2019) and in Portugal (56.5\%) (Gomes-Neves et al., 2014); but our students' scores were lower than Al-Shabib et al.'s (2016) study. In their study, the "personal hygiene", scores of the participants were found (80\%) in Saudi Arabia. Also, the lower level of the students' scores than food workers about each section in the present study are so different from Akoğlu and Tuncer's study (2017) conducted in Turkey. They found higher scores about food safety knowledge levels $(72.88 \%)$ of their students than previous studies of food workers. Besides, our students' food safety knowledge levels $(78.79 \%)$ were higher than their scores.

Table 3. Comparison of food safety knowledge, food safety practice, and personal hygiene practices among food workers and students

\begin{tabular}{|c|c|c|c|c|}
\hline \multicolumn{5}{|c|}{ Groups } \\
\hline & Foo & orkers $(n=75)$ & Gastronomy and Culinary Ar & idents $(n=80)$ \\
\hline Variables & $\begin{array}{l}\text { Possible range of } \\
\text { the scores }\end{array}$ & $\begin{array}{c}\text { Mean } \pm \text { Standard Deviation } \\
\text { Med (Min, Max) }\end{array}$ & $\begin{array}{c}\text { Mean } \pm \text { Standard Deviation } \\
\text { Med (Min, Max) }\end{array}$ & p value \\
\hline $\begin{array}{l}\text { (1) Food Safety Knowledge Total } \\
\text { Scores }\end{array}$ & $0-56$ & $\begin{array}{c}45.44 \pm 5.41 \\
48(28.56)\end{array}$ & $\begin{array}{c}38.35 \pm 12.37 \\
36(12.56)\end{array}$ & $<0.001$ *t \\
\hline $\begin{array}{l}\text { (2) Food Safety Practices Total } \\
\text { Scores }\end{array}$ & $0-36$ & $\begin{array}{c}35.89 \pm 0.92 \\
36(28.36)\end{array}$ & $\begin{array}{l}33.55 \pm 3.34 \\
36(24.36)\end{array}$ & $<0.001 * t$ \\
\hline (3) Personnel Hygiene Practices & $0-8$ & $\begin{array}{c}8 \pm 0.00 \\
8(8.8) \\
\end{array}$ & $\begin{array}{l}6.99 \pm 1.09 \\
7(4.8)\end{array}$ & $<0.001^{* \mathrm{MW}}$ \\
\hline
\end{tabular}

*p-value $<\mathbf{0 . 0 5}$ is significantly different

p-value used in the tables; Mann Whitney test result is $0.284^{\mathrm{MW}}$ and T-test is $0.005^{\mathrm{t}}$ 
Table 4. Comparison of total food safety knowledge scores of food workers and the students

\begin{tabular}{lcccc}
\hline Groups & Mean \pm SD & Median & Min-Max & $p$ value \\
\hline Food workers, $n=75$ & $89.33 \pm 5.36$ & 92.0000 & $72-94$ & $<0.001 *$ t \\
Students, $n=80$ & $78.89 \pm 13.14$ & 79.5000 & $41-94$ & \\
\hline Total & $83.94 \pm 11.39$ & 88.0000 & $41-87$ & \\
\hline
\end{tabular}

*p-value $<0.05$ is significantly different.

$\mathrm{p}$-value used in the tables; T-test is $0.005^{\mathrm{t}}$

\section{Section F: Relationships between Demographic Profiles and Participants' Food Safety Knowledge Levels}

Table 5. indicated that for food workers, gender, marital status, age, education level, frequency of hygiene education, working experience, monthly income had no significant association with total food safety knowledge $(\mathrm{p}>0.05)$. Similarly, some recent researches have reported no correlation was found between gender and food safety knowledge of food workers (Osaili et al., 2018; Taha et al. 2020). They did not found a positive correlation between marital status and occupation and food safety knowledge of food workers. The possible causes of our results may be depending on participants; male or female, married or single, participants are all working under similar conditions as food workers. On the other hand, in our study; hygiene certification, occupation, and working establishments had a significant association with total food safety scores of the food workers $(p<0.05)$. This result is parallel to the study of Rebouças et al. (2017). In their study, the restaurant staff had more personal hygiene information, better attitudes, and practices compared to the chief cooks and business managers, and the level of knowledge of the chief cooks and managers was insufficient in Brasil. The possible reasons for our results may be that food production personnel (especially head-cook/cook) are more aware of hygiene practices than other personnel (waiter, dishwasher, manager,.. etc). Besides, according to Turkish legislation, hygiene certification must be obtained by food workers to work in food establishments. Moreover, food workers from catering restaurants tend to be more disciplined than food workers that worked in kebap restaurants. And, this result may be dependant on various meals that are prepared-precooked/cooked and different procedures of cooling and reheating meals- in catering restaurants as opposed to kebap restaurants. Our results are different from Taha et al.'s (2020) study; they found a significant association between education, age, and experience of food workers in their research. However, we did not find a significant association between working experience and education level, monthly income, and frequency of hygiene education of food workers. This may be because of food workers who all have similar education levels, working experience, and similar monthly incomes in the present study. Considering the hygiene training frequencies of food workers; all of them took hygiene education, and the higher scores were found in the "one-time hygiene trained group". And other scores show some similarities in Table 5. This result may be depending on the effectiveness of the hygiene education taken by the participants that affected several aspects. These are education strategies, training areas, voluntary participation in education, a culture of work that is influenced by education, and food processors' beliefs, norms, and perceptions of their peers (Griffith et al., 2010; Taha et al., 2020). The possible reasons for these distinct results may be due to the efficiency of the training/practices. To ensure correct behaviors of food workers about their practices to prevent the occurrence of foodborne diseases and forging a positive food safety culture; the training programs should be designed to be comprehensive and according to necessities of the working conditions as well as suggestions of food workers.

Considering the students; as seen in Table 6; age, graduated high school, working in any food business had no significant association with total food safety knowledge ( $>>0.05)$. Similarly in a recent study conducted in Turkey has reported no significant association between age and food safety knowledge of food workers (Akoğlu and Tuncer, 2017). However, they found a significant association between the graduated high school, working in any food business in their study $(p<0.005)$. The probable causes of our results might be most of the students have similar age groups and most of them graduated from an Anatolia high school in which they were not given occupational education. Therefore, the students were not educated for a job in the food sector. Besides no correlation was found between students' experiences with and without doing part-time jobs. On the other hand, gender, hygiene certification, frequency of receiving hygiene education, and their class (education status) had a significant association with total food safety scores of the students $(\mathrm{p}<0.05)$. Our results have shown some similarities and differences with some recent studies conducted in Turkey by Akoğlu and Tuncer (2017) and Ertopcu et al. (2019). They had found an association between education level(class) and food safety training with total food safety scores of the students $(p<0.05)$. This finding is in agreement with our results. However, they had 
no association with gender and food safety scores of the students ( $>00.05$ ). Besides, Ertopcu et al. (2019) had found an association between gender and total food safety scores of the students $(p<0.05)$. Hygiene trained students have more scores than not trained students about food hygiene and safety in our study. This result is parallel to findings reported recently by
Osaili et al. (2018) in Jordan and Taha et al. (2020) in Saudi Arabia. It is well known that hygiene certification and effective hygiene education are mandatory factors to maintain food safety for gastronomy and culinary arts students as well as food workers.

Table 5. Comparison of total food safety scores by characteristics of food workers $(n=75)$

\begin{tabular}{|c|c|c|c|c|c|}
\hline \multicolumn{6}{|c|}{ Total Score } \\
\hline Group 1(Food workers) & & $\mathbf{N}$ & Mean \pm Sd & Median (Min, Max) & p value \\
\hline \multirow[t]{2}{*}{ Gender } & Female & 12 & $86 \pm 8.78$ & $90(72,96)$ & $0.284^{\mathrm{MW}}$ \\
\hline & Male & 63 & $89.97 \pm 4.24$ & $92(80,100)$ & \\
\hline \multirow[t]{3}{*}{ Age } & $<30$ years & 19 & $88.0 \pm 5.66$ & $88(72,96)$ & $0.348^{\mathbf{A}}$ \\
\hline & $30-40$ years & 35 & $89.37 \pm 6.21$ & $88(72,100)$ & \\
\hline & $>40$ years & 21 & $90.48 \pm 2.96$ & $92(84,96)$ & \\
\hline \multirow[t]{4}{*}{ Education Level } & Primary School & 24 & $87.83 \pm 5.84$ & $88(72,96)$ & $0.325^{\mathrm{KW}}$ \\
\hline & Middle School & 29 & $90.07 \pm 4.61$ & $88(80,96)$ & \\
\hline & High Scool & 15 & $88.33 \pm 5.98$ & $92(72,96)$ & \\
\hline & University & 7 & $91.43 \pm 4.86$ & $92(84,100)$ & \\
\hline \multirow[t]{2}{*}{ Hygiene Certification } & Yes & 68 & $93.71 \pm 3.15$ & $92(92,100)$ & $0.013 *$ MW \\
\hline & No & 7 & $88.88 \pm 5.35$ & $88(72,100)$ & \\
\hline Frequency of Receiving Hygiene & Once & 47 & $89.79 \pm 5.77$ & $92(72,100)$ & $0.642^{\mathrm{KW}}$ \\
\hline \multirow[t]{2}{*}{ Education } & 2 or 3 times & 21 & $88.57 \pm 4.78$ & $88(80,100)$ & \\
\hline & 4 andovertimes & 7 & $88.57 \pm 4.28$ & $88(84,96)$ & \\
\hline \multirow[t]{4}{*}{ Occupation } & Chefcook & 34 & $90.82 \pm 4.24$ & $92(80,100)$ & $0.044 * \mathrm{t}$ \\
\hline & Waiter & 12 & $90.33 \pm 2.67$ & $92(84,92)$ & \\
\hline & Assistantcook & 16 & $87.5 \pm 4.35$ & $88(80,96)$ & \\
\hline & Other (manager, dishwasher, etc.) & 13 & $86.77 \pm 8.85$ & $92(72,96)$ & \\
\hline \multirow[t]{4}{*}{ Working Experience } & $0-6$ years & 17 & $87.06 \pm 7.28$ & $92(72,96)$ & $0.154^{\mathrm{KW}}$ \\
\hline & $6-11$ years & 31 & $89.68 \pm 5.04$ & $88(80,100)$ & \\
\hline & $12-20$ years & 18 & $91.11 \pm 4.24$ & $92(80,100)$ & \\
\hline & $>20$ years & 9 & $88.89 \pm 2.67$ & $88(84,92)$ & \\
\hline \multirow[t]{3}{*}{ Monthly Income (Türkish Liras) } & $2500-3000$ & 49 & $88.98 \pm 5.80$ & $92(72,100)$ & $0.635^{\mathrm{KW}}$ \\
\hline & $3000-3500$ & 21 & $89.71 \pm 4.66$ & $92(80,96)$ & \\
\hline & $3500-4000$ & 5 & $91.20 \pm 3.35$ & $92(88,96)$ & \\
\hline \multirow[t]{2}{*}{ Marital Status } & Single & 13 & $89.54 \pm 4.18$ & $92(80,96)$ & $0.994^{\mathrm{MW}}$ \\
\hline & Married & 62 & $89.29 \pm 5.60$ & $92(72,100)$ & \\
\hline \multirow[t]{2}{*}{ Working Establishments } & Catering & 55 & $88.51 \pm 5.76$ & $88(72,100)$ & $0.005 * \mathrm{t}$ \\
\hline & Kebap Restaurant & 20 & $91.60 \pm 3.15$ & $92(72,100)$ & \\
\hline
\end{tabular}

*p-value $<\mathbf{0 . 0 5}$ is significantly different

p-value used in the tables; Mann Whitney test result is $0.284^{\mathrm{MW}}$, T-test is $0.005^{\mathrm{t}}$, for Anova, it is $0.348^{\mathrm{A}}$ and Kruskal-Wallis is $0.325^{\mathrm{KW}}$ 
Table 6. Comparison of total food safety scores by characteristics of the $\operatorname{students}(n=80)$

\begin{tabular}{|c|c|c|c|c|c|}
\hline \multicolumn{6}{|c|}{ Total Score } \\
\hline Group 2(Students) & & $\mathbf{N}$ & Mean \pm Sd & Median (Min, Max) & p value \\
\hline \multirow[t]{2}{*}{ Gender } & Female & 54 & $77.19 \pm 11.93$ & $76(48,100)$ & $0.026 * t$ \\
\hline & Male & 26 & $82.42 \pm 14.98$ & $84.5(41,100)$ & \\
\hline \multirow[t]{3}{*}{ Age } & 18 & 11 & $74.10 \pm 7.67$ & $71(63,88)$ & \\
\hline & 19 & 19 & $77.84 \pm 15.91$ & $80(18,100)$ & $0.338^{\mathrm{KW}}$ \\
\hline & $\geq 20$ & 50 & $80.34 \pm 13.14$ & $79.5(41,100)$ & \\
\hline \multirow[t]{4}{*}{ Graduated High School } & Occupation high school & 21 & $78.52 \pm 14.66$ & $80(41,99)$ & \\
\hline & Anadolu high school & 42 & $80.02 \pm 12.54$ & $79(51,100)$ & \\
\hline & Basic-Open highs chool & 6 & $74.67 \pm 9.60$ & $71.50(66,91)$ & \\
\hline & Religious high school & 11 & $77.55 \pm 14.99$ & $78(48,99)$ & $0.792^{\mathrm{KW}}$ \\
\hline \multirow[t]{2}{*}{ Hygiene Certification } & Yes & 14 & $87.07 \pm 9.45$ & $87.50(71,100)$ & \\
\hline & No & 66 & $77.15 \pm 13.20$ & $77(41,100)$ & $0.008 * M W$ \\
\hline \multirow[t]{3}{*}{ Frequency of Receiving Hygiene Education } & 0 & 51 & $74.33 \pm 12.73$ & $75(41-100)$ & \\
\hline & Once & 15 & $87.80 \pm 8.95$ & $88(64,99)$ & $<0.001 * \mathrm{KW}$ \\
\hline & 2 or 3 times & 14 & $85.93 \pm 10.64$ & $86(70,100)$ & \\
\hline \multirow[t]{2}{*}{ Working in any Food Business } & Yes & 32 & $80.47 \pm 14.90$ & $82(41,100)$ & \\
\hline & No & 48 & $77.83 \pm 11.87$ & $79(48,99)$ & $0.293^{\mathrm{t}}$ \\
\hline \multirow[t]{2}{*}{ Education Status } & 1. Class & 44 & $70.68 \pm 9.77$ & $71(41,88)$ & \\
\hline & 2. Class & 36 & $88.92 \pm 9.17$ & $90(58,100)$ & $<0.001 * \mathrm{t}$ \\
\hline
\end{tabular}

*p-value $<\mathbf{0 . 0 5}$ is significantly different

$\mathrm{p}$-value used in the tables; Mann Whitney test result is $0.284^{\mathrm{MW}}$, T-test is $0.005^{\mathrm{t}}$, for Anova it is $0.348^{\mathrm{A}}$ and Kruskal-Wallis is $0.325^{\mathrm{KW}}$

\section{Conclusions}

In this study, we compared knowledge levels in safe food production and hygiene practices between gastronomy and culinary arts students and food workers. Our results indicated that students had less information in some important food safety practices such as time/temperature control, storage/holding temperatures of the meals, cooling, freezing, and thawing methods of the food, important foodborne pathogens, preventive methods for cross-contamination, and the importance of handwashing than food workers. However, the food workers had less knowledge in some aspects including time and temperature control, holding/storage temperature of the meals especially cross-contamination. Besides, two groups highly cared about the importance of personal hygiene applications in the food production line. Food workers' safe food knowledge and practices can be crucial in public health and the economic standing of businesses in the catering industry. Also, the students will be food production workers or managers/chefs in the future. Their food safety knowledge level and practices also will affect either positively or negatively on the economy and public health Therefore, hygiene education and practices and HACCP education should be given to both groups, routinely. The most proactive method for guaranteeing safe food production in the future may be an effective HACCP and ISO 22000 Quality Management Systems implementation in food establishments and especially the catering sector.

\section{Compliance with Ethical Standard}

Conflict of interests: The author declares that for this article they have no actual, potential or perceived conflict of interests.

Ethics committee approval: This study was approved by the Scientific Research, and Publication Ethics Committee of Osmaniye Korkut Ata University was received on 11.05.2020 with the document number $2020 / 18 / 3$.

\section{Funding disclosure: -}

Acknowledgments: The author is thankful for the catering kitchens and kebab restaurants staffs and gastronomy and culinary arts students who participated in this research.

\section{Disclosure: -}

\section{References}

Akoğlu, A., Tuncer, T. (2017). The level of food safety knowledge of gastronomy and culınary arts students in Turkey. International Journal of Agriculture, Environment and Bioresearch, 2(6), 2456-8643.

Al-Kandari, D., Al-abdeen, J., Sidhu, J. (2019). Food safety knowledge attitudes, and practices of food handlers in restaurants in Kuwait. Food Control, 103, 103-110. https://doi.org/10.1016/j.foodcont.2019.03.040 
Alqurashi, N. A., Priyadarshini, A., Jaiswal, A. K. (2019). Evaluating food safety knowledge, and practices among foodservice staff in Al Madinah hospitals, Saudi Arabia. Safety, 5(1), 9.

https://doi.org/10.3390/safety5010009

Al-Shabib, N.A., Mosilhey, S.H., Husain, F.M. (2016). Cross-sectional study on food safety knowledge, attitude, and practices of male food handlers employed in restaurants of King Saud University, Saudi Arabia. Food Control, 59, 212217.

https://doi.org/10.1016/j.foodcont.2015.05.002

Anonymous (2013). Hygiene Education Regulation: Official Gazette, Number: 28698, History; July 5, Ankara.

Baş, M., Ersun, A.Ş., Kıvanç, G. (2006). The evaluation of food hygiene knowledge, attitudes, and practices of food handlers' in food businesses in Turkey. Food Control, 17(4), 317322.

https://doi.org/10.1016/j.foodcont.2004.11.006

Clayton, D.A., Griffith, C.J., Price, P., Peters, A.C. (2002). Food handlers' beliefs and self-reported practices. International Journal of Environmental Health Research, 12, 25-39. (Ed.), (Rev. 4 ed.).

https://doi.org/10.1080/09603120120110031

Çakıroğlu, F.P., Uçar, A. (2008). Employees' perception of hygiene in the catering industry in Ankara (Turkey). Food Control, 19(1), 9-15.

https://doi.org/10.1016/j.foodcont.2007.01.001

Da Cunha, D.T., Stedefeldt, E., de Rosso, V.V. (2014). The role of theoretical food safety training on Brazilian food handlers' knowledge, attitude and practice. Food Control, 43, 167-174.

https://doi.org/10.1016/j.foodcont.2014.03.012

Darko, S., Mills-Robertson, F.C., Wireko-Manu, F.D. (2015). Evaluation of some hotel kitchen staff on their knowledge on food safety and kitchen hygiene in the Kumasi Metropolis. International Food Research Journal, 22(6), 2664-2669.

Draeger, C.L., Akutsu, R.D.C.C.D.A., Zandonadi, R.P., Da Silva, I.C.R., Botelho, R.B.A., Araújo, W.M.C. (2019). Brazilian foodborne disease national survey: Evaluating the landscape after 11 years of implementation to advance research, policy, and practice in public. Nutrients, 11(1), 40. https://doi.org/10.3390/nu11010040
EC (2004). Regulation (EC) No.852/2004 of the European Parliament and of the Council of 29 April 2004 on the hygiene of foodstuffs. Official Journal of the European Union, L226/3, 25 June.

EFSA and ECDC (2015). The European Union summary report on trends and sources of zoonoses, zoonotic agents, and food-borne outbreaks in 2013, European Food Safety Authority and European Centre for Disease Prevention and Control. EFSA Journal, 13(1), 1-162.

https://doi.org/10.2903/j.efsa.2015.3991

Ertopcu, İ., Avcıkurt, A., Çetinkaya, T. (2019). Aşçılık programı öğrencilerinin hijyen bilgi düzeyleri üzerine bir araştırma (A research on the hygiene knowledge levels of culinary program students). Journal of Tourism and Gastronomy Studies, 2187, 2203.

https://doi.org/10.21325/jotags.2019.467

Giritlioglu, I., Batman, O., Tetik, N. (2011). The knowledge and practice of food safety and hygiene of cookery students in Turkey. Food Control, 22(6), 838-842.

https://doi.org/10.1016/j.foodcont.2010.09.016

Gomes-Neves, E., Antunes, P., Manageiro, V., Gärtner, F., Caniça, M., da Costa, J.M.C., Peixe, L. (2014). Clinically relevant multidrug-resistant Salmonella enterica in swine and meat handlers at the abattoir. Veterinary Microbiology, 168(1), 229-233.

https://doi.org/10.1016/j.vetmic.2013.10.017

Gong, S., Wang, X., Yang, Y., Bai, L. (2016). Knowledge of food safety, and handling in households: A survey of food handlers in Mainland China. Food Control, 64, 45-53.

https://doi.org/10.1016/j.foodcont.2015.12.006

Griffith, C.J., Livesey, K.M., Clayton, D. (2010). The assessment of food safety culture. British Food Journal, 112(4), 439-456.

https://doi.org/10.1108/00070701011034448

Güven, E. (2010). A study on the determination of nutrition habits and food safety knowledge of individuals from different education and income levels living in Yalova province. Tekirdağ, Turkey: Namık Kemal University, Institute of Science, MSc. thesis. Accessed from higher education institution national thesis center database (283196).

Lund, B.M. (2015). Microbiological food safety for vulnerable people. International Journal of Environmental Research and Public Health, 12(8), 10117-10132. 
https://doi.org/10.3390/ijerph120810117

Marriott, N.G., Gravani, R.B. (2006). Foodservice sanitation. Principles of Food Sanitation, 371-391. Springer, food Science Text Series, Book Series, 1995-2021.

Mehta, S. (2020). Nutritional status and COVID-19: an opportunity for lasting change? Clinical Medicine. 20(3), 270273.

https://doi.org/10.7861/clinmed.2020-0187

Ncube, F., Kanda, A., Chijokwe, M., Mabaya, G., Nyamugure, T. (2020). Food safety knowledge, attitudes and practices of restaurant food handlers in a lower-middle-income country. Food Science \& Nutrition, 8(3), 1677-1687.

https://doi.org/10.1002/fsn3.1454

Osaili, T.M., Obeidat, B.A., Jamous, D.O.A., Bawadi, H.A. (2011). Food safety knowledge, and practices among college female students in north of Jordan. Food Control, 22, 269-276.

https://doi.org/10.1016/j.foodcont.2010.07.009

Osaili, T.M., Obeidat, B.A., Hajeer, W.A., Al-Nabulsi, A.A. (2017). Food safety knowledge among food service staff in hospitals in Jordan. Food Control, 78, 279-285.

https://doi.org/10.1016/j.foodcont.2017.02.057

Osaili, T.M., Al-Nabulsi, A.A., Krasneh, H.D.A. (2018). Food safety knowledge among food service staff at the universities in Jordan. Food Control, 89, 167-176.

https://doi.org/10.1016/j.foodcont.2018.02.011

Palulu S. (2014). Knowledge level of employees about food hygiene in the workplace relating to food production and sale in the center of Edirne. Trakya University, Institute of Health Sciences, MSc thesis. Accessed from higher education institution national thesis center database (359301).

Pichler, J., Ziegler, J., Aldrian, U., Allerberger, F. (2014). Evaluating levels of knowledge on food safety among food handlers from restaurants and various catering businesses in Vienna, Austria 2011/2012. Food Control, 35, 33-40. https://doi.org/10.1016/j.foodcont.2013.06.034

Rebouças, L.T., Santiago, L.B., Martins, L.S., Menezes, A.C.R., Araújo, M.D.P.N., de Castro Almeida, R.C. (2017). Food safety knowledge and practices of food handlers, head chefs and managers in hotels' restaurants of Salvador, Brazil. Food Control, 73, 372-381.

https://doi.org/10.1016/j.foodcont.2016.08.026
Sani, N.A., Siow, O.N. (2014). Knowledge, attitudes, and practices of food handlers on food safety in food service operations at the Universiti Kebangsaan Malaysia. Food Control, 37, 210-217.

https://doi.org/10.1016/j.foodcont.2013.09.036

Smigic, N., Djekic, I., Martins, M.L., Rocha, A., Sidiropoulou, N., Kalogianni, E.P. (2016). The level of food safety knowledge in food establishments in three European countries. Food Control, 63, 187-194.

https://doi.org/10.1016/j.foodcont.2015.11.017

Sun, H., Wan, Y., Du, P., Bai, L. (2020). The epidemiology of monophasic Salmonella Typhimurium. Foodborne Pathogens and Disease, 17(2), 87-97.

https://doi.org/10.1089/fpd.2019.2676

Taha, S., Osaili, T.M., Saddal, N.K., Al-Nabulsi, A.A., Ayyash, M.M., Obaid, R.S. (2020). Food safety knowledge among food handlers in food service establishments in United Arab Emirates. Food Control, 110, 106968.

https://doi.org/10.1016/j.foodcont.2019.106968

Taylor, J., Garat, J.P., Simreen, S., Sarieddine, G. (2015). An industry perspective: A new model of food safety culture excellence and the impact of audit on food safety standards. Worldwide Hospitality and Tourism Themes, 7, 78-89. https://doi.org/10.1108/WHATT-12-2014-0041

Tokuc, B., Ekuklu, G., Berberoğlu, U., Bilge, E., Dedeler, H. (2009). Knowledge, attitudes and self-reported practices of food service staff regarding food hygiene in Edirne, Turkey. Food Control, 20(1), 565-568.

https://doi.org/10.1016/j.foodcont.2008.08.013

Tuncer, T., Akoğlu, A. (2020). Food safety knowledge of food handlers working in hotel kitchens in Turkey. Food and Health, 6(2), 67-89.

https://doi.org/10.3153/FH20009

USDA. (2013). United States Department of Agriculture Food Safety and Inspection Service, https://www.fsis.usda.gov/food-safety/safe-food-handlingand-preparation (accessed date; 16 May 2021)"

USFDA Food and Drug Administration Food Code (2017). https://www.fda.gov/food/retail-food-protection/fdafood-code (accessed date: 16 May 2021) 